\title{
HUBUNGAN KADAR ASPAL DENGAN VARIASI KADAR FILL- ER BATU TABAS PADA CAMPURAN AC-WC
}

\author{
Putu Hendriawan Wijaya \\ Boedi Rahardjo, Pranoto
}

\begin{abstract}
Abstrak: Penurunan ketahanan (durabilitas) lapisan perkerasan terutama perkerasan lentur akibat permukaan jalan sering terendam air. Lapis perkerasan lentur yang sering mengalami kerusakan adalah lapis aspal beton AC-WC (Asphalt Concrete-Wearing Course) atau lapis aus. Kualitas aspal beton dapat ditingkatkan menggunakan filler sebagai bahan pengisi ke dalam campuran. Limbah batu tabas dimanfaatkan sebagai filler atau bahan pengisi untuk membantu kinerja pada campuran aspal beton, meningkatkan kualitas jalan dan mengurangi dampak kerusakan lingkungan. Tujuan penelitian: (1) mendeskripsikan karakteristik bahan campuran aspal beton AC-WC. (2) hubungan antara kadar aspal dengan variasi kadar filler batu tabas pengujian marshall dan IKS. Hasil penelitian: (1) karakteristik bahan campuran aspal beton AC-WC yang meliputi: (a) berat jenis agregat kasar 2,64, agregat halus 2,29 \& filler batu tabas 3,08, penyerapan agregat kasar 2,39\% dan agregat halus 1,48\%, dan keausan agregat kasar $29,02 \%$. (b) berat jenis aspal 1,03 , penetrasi aspal $66,55 \mathrm{~mm}$, titik lembek aspal $50,5^{\circ} \mathrm{C}$, daktilitas aspal $130,33 \mathrm{~cm}$, titik nyala aspal suhu $339^{\circ} \mathrm{C}$ dengan titik bakar suhu $344^{\circ} \mathrm{C}$, dan kehilangan berat aspal sebesar $0,0 \%$. (2) hubungan campuran AC-WC menggunakan variasi kadar filler batu tabas pengujian marshall dan IKS, yaitu: (a) Stabilitas pada kadar filler batu tabas $0 \%$ dengan kadar aspal 6\% meningkat dan memperoleh nilai tertinggi yaitu $1749,29 \mathrm{~kg}$, lalu menurun hingga kadar aspal 7\%, (b) Flow kadar filler batu tabas 75\% dengan kadar aspal 5,5\% menurun dan memperoleh nilai terendah yaitu 1,64 mm, lalu meningkat hingga kadar aspal 7\%, (c) MQ tertinggi diperoleh kadar filler batu tabas $75 \%$ dengan kadar aspal 5,5\% sebesar 1114,63 kg/mm, lalu kadar filler batu tabas $100 \%$ dengan kadar aspal $7 \%$ menurun hingga $301,21 \mathrm{~kg} / \mathrm{mm}$, (d) VIM aspal beton secara keseluruhan menurun seiring bertambahnya kadar aspal, (e) VMA aspal beton secara keseluruhan meningkat seiring bertambahnya kadar aspal, (f) VFA meningkat seiring bertambahnya kadar aspal. (g) IKS tertinggi diperoleh pada campuran dengan kadar filler batu tabas 75\% kadar aspal 6,5\% yaitu 98,18\%.
\end{abstract}

Kata-kata kunci: batu tabas, kadar filler, AC-WC, parameter marshall, IKS

\begin{abstract}
Decreased durability of the pavement layer, especially the flexible pavement due to the road surface is often submerged in water. Flexible pavement layers that are often damaged are $A C-W C$ (Asphalt Concrete-Wearing Course) asphalt or wear layers. The quality of asphalt concrete can be improved using filler as filler material into the mixture. Tabas rock waste is used as filler to help the performance of the concrete asphalt mixture, improve road quality and reduce the impact of environmental damage. Research objectives: (1) describe the characteristics of $A C$-WC concrete asphalt mixture. (2) the relationship between asphalt content with variations in the content of tabas rock marshall testing and IKS. The results of the study: (1) the characteristics of $A C-W C$ concrete asphalt mix material which include: (a) the specific gravity of coarse aggregate 2.64, fine aggregate 2.29 \& tabas stone filler 3.08, absorption of coarse aggregate $2.39 \%$ and aggregate fine $1.48 \%$, and gross aggregate wear 29.02\%. (b) asphalt density 1.03, asphalt penetration $66.55 \mathrm{~mm}$, asphalt softening point $50.5^{\circ} \mathrm{C}$, asphalt ductility $130.33 \mathrm{~cm}$, asphalt flashpoint temperature $339^{\circ} \mathrm{C}$ with firing point temperature 344 ${ }^{\circ} C$, and loss asphalt weight of $0.0 \%$. (2) the relationship of $A C$-WC mixture using variations in the content of tabas rock marshall testing and IKS, namely: (a) Stability at 0\% tabas stone content with $6 \%$ asphalt content increased and obtained the highest value of $1749.29 \mathrm{~kg}$, then decreased to asphalt content of $7 \%$, (b) Flow of $75 \%$ tabas rock filler with $5.5 \%$ asphalt content decreased and obtained the lowest value of $1.64 \mathrm{~mm}$, then increased to asphalt content of $7 \%$, (c) the highest MQ obtained by filler content 75\% tabas stone with $5.5 \%$ asphalt content of $1114.63 \mathrm{~kg} / \mathrm{mm}$, then $100 \%$ tabas stone content with $7 \%$ asphalt content decreased to 301.21 $\mathrm{kg} / \mathrm{mm},(\mathrm{d})$ the overall concrete bitumen VIM decreased increasing asphalt content, (e) VMA asphalt concrete as a whole increases with increasing asphalt content, (f) VFA increases with increasing asphalt content. (g) The highest IKS was obtained in a mixture with 75\% tabas rock filler content, $6.5 \%$ asphalt level, namely $98.18 \%$.
\end{abstract}

Key words: tabas stone, filler content, $A C$-WC, marshall parameters, IKS

Putu Hendriawan Wijaya adalah Alumni Jurusan Teknik Sipil Fakultas Teknik UM; E-mail: hendrikazama1@gmail. com; Boedi Rahardjo dan Pranoto adalah Dosen Jurusan Teknik Sipil Fakultas Teknik Universitas Negeri Malang; Jalan Semarang No.5 Malang 65145; E-mail: boedi.rahardjo.ft@um.ac.id dan Kangnoto20@gmail.com 


\section{PENDAHULUAN}

Lapisan AC-WC merupakan lapisan yang berhubungan langsung dengan ban kendaraan dan dirancang untuk tahan terhadap tekanan roda ban kendaraan, gaya geser, pengaruh cuaca, dan kedap air untuk lapisan di bagian bawah (Tahir, 2009). Aspal beton AC-WC yang direncanakan sebagai lapis perkerasan perlu dilakukan pengujian terlebih dahulu untuk mengetahui karakteristik pada campuran beraspal. Parameter yang ditinjau untuk mengetahui karakteristik suatu campuran beraspal yaitu parameter Marshall. Menurut Khuntia et al. (2014), pengujian Marshall merupakan sebagian dari prosedur desain campuran untuk mengoptimalkan desain kadar aspal dan mengontrol kualitas campuran beraspal. Uji Marshall dilakukan untuk mengetahui karakteristik campuran yaitu nilai-nilai stabilitas, flow, MQ, VIM, VMA, dan VFA. Parameter Indeks Kekuatan Sisa (IKS) merupakan pengujian yang dilakukan pada aspal beton yang bertujuan untuk menentukan tingkat durabilitas suatu campuran. Indeks Kuat Sisa menunjukkan besar kehilangan stabilitas akibat perendaman yang menggambarkan tingkat kerusakan oleh air.

Kualitas aspal beton dapat ditingkatkan dengan menggunakan filler sebagai bahan pengisi ke dalam campuran. Fungsi filler pada campuran aspal beton adalah untuk mengisi rongga dalam campuran, meningkatkan daya ikat aspal beton serta meningkatkan stabilitas dari campuran aspal beton (Zulfhazli et al., 2016). Menurut Intara et al. (2013) di Bali terdapat banyak usaha kerajinan menggunakan batu tabas untuk diolah menjadi hiasan maupun ornamen pada bangunan tradisional Bali. Limbah batu tabas yang dihasilkan dari usaha kerajinan yang terdapat di sepanjang daerah perbatasan Denpasar dan Gianyar hingga tahun 2019 telah mencapai sekitar 96 ton. Batu tabas dimanfaatkan sebagai filler atau bahan pengisi untuk membantu kinerja pada campuran aspal beton, meningkatkan kualitas jalan dan mengurangi dampak kerusakan lingkungan akibat limbah yang tidak diolah dengan maksimal.

\section{METODE}

Agregat diperoleh dari AMP (Asphalt Mix Plant) PT. Piranti Utomo Makmur kabupaten Malang. Agregat kasar yang digunakan dalam penelitian adalah agregat yang tertahan pada saringan No. 4 (4,75 mm). Agregat halus terdiri dari kerikil sisa pecahan batu dan pasir alam yang lolos saringan No. 4 (4,75 mm) dan tertahan pada saringan No. $200(0,075$ mm) (Spesifikasi Umum, 2018). Limbah batu tabas diperoleh dari indsutri pengrajin patung di kabupaten Karangasem, sedangkan semen yang digunakan adalah Portland Cement. Filler batu tabas dan semen sebagai bahan pengisi pada campuran benda uji harus lolos saringan No. 200 (0,075 mm). Aspal yang digunakan adalah aspal dari PT. Pertamina dengan penetrasi 60/70 sebagai campuran untuk pembuatan benda uji aspal beton.

Pemeriksaan agregat dilakukan untuk mengetahui karakteristik agregat sebelum digunakan dalam pembuatan benda uji. Berikut adalah beberapa pengujian agregat yang akan dilakukan.

1. Pengujian Berat Jenis dan Penyerapan Air Agregat Kasar berdasarkan SNI 19692008.

2. Pengujian Berat Jenis dan Penyerapan Air Agregat Halus SNI 1970-2008.

3. Pengujian Abrasi dengan Los Angeles dilaksanakan sesuai dengan SNI 24172008.

4. Bahan pengisi atau filler dari batu tabas perlu dilakukan pengujian berat jenis filler berdasarkan SNI 15-2531-1991.

Pemeriksaan aspal yang digunakan dalam 
pembuatan benda uji adalah aspal dengan penetrasi 60/70. Berikut merupakan pengujianpengujian aspal.

1. Penetrasi Bahan Bitumen berdasarkan SNI 2456-2011.

2. Pengujian Berat Jenis dilakukan sesuai dengan SNI 2441-2011.

3. Pengujian Titik Lembek berdasarkan SNI 2434-2011.

4. Pengujian Titik Nyala dan Titik Bakar dengan Cleveland Open Cup SNI 24332011.

5. Pengujian Daktilitas berdasarkan SNI 24322011.

6. Pengujian Kehilangan Berat dilakukan sesuai dengan SNI 06-2440-1991.

Kadar aspal untuk benda uji sebesar 5\%, $5,5 \%, 6 \%, 6,5 \%, 7 \%$. Kadar filler batu tabas sebagai pengganti sebagian semen yang direncanakan pada pembuatan benda uji aspal beton AC-WC adalah $0 \%$ (semen 100\%), $25 \%$ (semen 75\%), 50\% (semen 50\%), 75\% (semen 25\%) dan 100\% (semen 0\%) sehingga setiap kadar aspal memiliki lima variasi kadar filler. Benda uji yang dibuat pada penelitian ini adalah aspal beton AC-WC (Asphalt Concrete-Wearing Course). Stabilitas benda uji untuk pengujian IKS dengan perendaman dalam waterbath selama 24 jam dengan suhu $60^{\circ} \mathrm{C}$ akan dibandingkan dengan benda uji pada perendaman 30 menit dari pengujian Marshall yang menghasilkan nilai stabilitas tertinggi.

Pengujian untuk mengetahui nilai IKS dilakukan dengan cara perendaman benda uji dengan variasi kadar aspal dan filler ke dalam water bath pada suhu $60^{\circ} \mathrm{C}$ selama 30 menit dan 24 jam untuk memperoleh nilai stabilitas sisa. Menurut Ambarwati \& Arifin (2009) nilai stabilitas Marshall yang didapat dari kedua perendaman tersebut akan ditentukan besar nilai Indeks Kekuatan Sisa (IKS) Marshall dengan menggunakan Persamaan 1 dibawah ini.

$\mathrm{IKS}=\frac{\mathrm{S}_{2}}{\mathrm{~S}_{1}} \times 100$

Dimana:

S1 = Nilai rata-rata stabilitas Marshall setelah perendaman selama 30 menit $(\mathrm{kg})$

S2 = Nilai rata-rata stabilitas Marshall setelah perendaman selama 24 jam $(\mathrm{kg})$

IKS = Indeks Kekuatan Sisa (\%)

\section{HASIL}

\section{Pengujian Agregat Kasar, Halus, Filler, dan Aspal}

a) Pengujian Agregat Kasar, Halus, dan Filler

Bahan agregat yang akan digunakan dalam pembuatan benda uji dilakukan pengujian terlebih dahulu sehingga dapat diketahui bahwa bahan tersebut layak digunakan. Berikut ini adalah hasil pengujian agregat yang terdapat pada Tabel 1 .

Hasil pengujian agregat kasar, halus dan filler dari Tabel 1 di atas diperoleh nilai berat jenis SSD agregat kasar sebesar 2,64 dan penyerapan agregat kasar 2,39\%. Nilai keausan agregat pada pengujian Los Angeles diperoleh sebesar 29,02\% dari nilai maksimal $40 \%$ sehingga agregat kasar dapat digunakan pada campuran beraspal.

Berat jenis filler yang diuji perbandingan semen PC dan batu tabas dengan variasi kadar batu tabas $0 \%, 25 \%, 50 \%, 75 \%$, dan $100 \%$. Hasil pengujian berat berat jenis filler BT $0 \%$ (semen PC 100\%) diperoleh sebesar 3,03, BT $25 \%$ sebesar 3,122 , BT $50 \%$ sebesar 3,033, BT 75\% sebesar 3,02, dan BT 100\% sebesar 3,08 . 
12 JURNAL BANGUNAN, VOL. 24, NO.2, OKTOBER 2019: 9-18

Tabel 1. Data Hasil Pengujian Agregat Kasar, Halus dan Filler

\begin{tabular}{lclll}
\hline \multicolumn{1}{c}{ Pengujian } & Metode & Hasil Pengujian & & Spesifikasi \\
\hline Berat jenis agregat kasar & SNI 1969-2008 & $\begin{array}{l}\text { Berat Jenis Bulk } \\
\text { Berat Jenis SSD } \\
\text { Berat Jenis Semu }\end{array}$ & $\begin{array}{l}=2,58 \\
=2,64\end{array}$ & Min 2,5 \\
& & & $=2,39$ & Max 3 \\
\hline Penyerapan agregat kasar (\%) & SNI 1969-2008 & & $=2,26$ & \\
\hline & & Berat Jenis Bulk & $=2,29$ & - \\
Berat jenis agregat halus & SNI 1970-2008 & Berat Jenis SSD & $=2,34$ & \\
& & Berat Jenis Semu & $=1,48$ & - \\
\hline Penyerapan agregat halus (\%) & SNI 1970-2008 & & $=29,02$ & Max 40 \\
\hline Keausan (\%) & SNI 2417-2008 & & $=3,03$ & - \\
\hline Berat Jenis Filler Portland Ce- & SNI 03-2531-1991 & & $=3,08$ & \\
ment (BT 0\%) & & & & \\
\hline Berat Jenis Filler & & & $=3,122$ & \\
Batu Tabas (BT 100\%) & & & $=3,033$ & \\
BT 25\% & SNI 03-2531-1991 & & $=3,02$ & \\
BT 50\% & & & & \\
BT 75\% & & & & \\
\hline
\end{tabular}

\section{b) Pengujian Aspal}

Aspal yang akan digunakan harus dilakukan pengujian terlebih dahulu untuk mengetahui aspal yang digunakan dalam campuran sesuai dengan standar yang ditentukan. Berikut merupakan hasil pengujian aspal yang terdapat pada Tabel 2 .

Tabel 2. Data Hasil Pengujian Aspal

\begin{tabular}{|c|c|c|c|}
\hline Pengujian & Metode & $\begin{array}{c}\text { Hasil } \\
\text { Pengujian }\end{array}$ & $\begin{array}{c}\text { Spesifi- } \\
\text { kasi }\end{array}$ \\
\hline $\begin{array}{l}\text { Berat } \\
\text { Jenis }\end{array}$ & $\begin{array}{c}\text { SNI 06- } \\
2441-2011 \\
\end{array}$ & 1,03 & $\geq 1,0$ \\
\hline $\begin{array}{c}\text { Penetrasi } \\
(\mathrm{mm})\end{array}$ & $\begin{array}{c}\text { SNI 06- } \\
2456-2011\end{array}$ & 66,55 & $60-70$ \\
\hline $\begin{array}{l}\text { Titik lem- } \\
\text { bek }\left({ }^{\circ} \mathrm{C}\right)\end{array}$ & $\begin{array}{c}\text { SNI 06- } \\
2434-2011 \\
\end{array}$ & 50,5 & $\geq 48$ \\
\hline $\begin{array}{l}\text { Daktilitas } \\
\quad(\mathrm{cm})\end{array}$ & $\begin{array}{c}\text { SNI } \\
06-2432- \\
2011 \\
\end{array}$ & 130,33 & $\geq 100$ \\
\hline \multirow{2}{*}{$\begin{array}{c}\text { Titik } \\
\text { Nyala dan } \\
\text { Titik Ba- } \\
\text { kar }\left({ }^{\circ} \mathrm{C}\right)\end{array}$} & \multirow{2}{*}{$\begin{array}{c}\text { SNI } \\
\text { 06-2433- } \\
2011\end{array}$} & $\begin{array}{l}\text { Titik nyala } \\
=339\end{array}$ & \multirow{2}{*}{$\geq 232$} \\
\hline & & $\begin{array}{c}\text { Titik ba- } \\
\text { kar }=344\end{array}$ & \\
\hline $\begin{array}{c}\text { Kehilan- } \\
\text { gan berat } \\
(\%)\end{array}$ & $\begin{array}{c}\text { SNI 06- } \\
2440-1991\end{array}$ & 0,0 & $\leq 0,8$ \\
\hline
\end{tabular}

Hasil pengujian pada Tabel 2 sebelumnya diperoleh berat jenis aspal senilai 1,03. Nilai yang diperoleh dari pengujian penetrasi aspal senilai $66,55 \mathrm{~mm}$. Nilai titik lembek aspal diperoleh suhu $50,5^{\circ} \mathrm{C}$. Hasil pengujian daktilitas berupa nilai rata-rata yaitu sebesar $130,33 \mathrm{~cm}$. Hasil pengujian titik nyala berada pada suhu $339^{\circ} \mathrm{C}$ sedangkan titik bakar berada pada suhu $344^{\circ} \mathrm{C}$. Hasil pengujian kehilangan berat aspal sebesar $0,0 \%$. Seluruh hasil pengujian aspal telah memenuhi syarat spesifikasi yang telah ditentukan.

\section{Pengujian Marshall dan Indeks Kekua tan Sisa \\ a) Pengujian Marshall}

Pengujian yang dilakukan bertujuan untuk mendapatkan hasil berupa nilai stabilitas, flow, MQ, VIM, VMA, VFA. Hasil dari pengujian ini dapatdilihatpadaTabel3 sampaidenganTabel8.

Stabilitas adalah kemampuan lapis permukaan aspal dalam menerima beban sampai terjadi kelelehan plastis yang dinyatakan dalam satuan kilogram atau pound. Stabilitas cenderung meningkat seiring bertambahnya kadar aspal hingga mencapai nilai maksimum, lalu stabilitas akan menurun. 
Tabel 3. Nilai Stabilitas Aspal Beton AC-WC

\begin{tabular}{|c|c|c|c|c|c|c|}
\hline \multicolumn{7}{|c|}{ STABILITAS (kg) } \\
\hline \multirow{2}{*}{$\begin{array}{c}\text { \% Kadar Filler Batu } \\
\text { Tabas }\end{array}$} & \multicolumn{5}{|c|}{ \% Kadar Aspal Terhadap Berat Campuran } & \multirow{2}{*}{$\frac{\text { Spesifikasi }}{\text { Minimal }}$} \\
\hline & 5 & 5,5 & 6 & 6,5 & 7 & \\
\hline $0 \%$ & 1716,92 & 1740,77 & 1749,29 & 1463,71 & 1364,00 & \multirow{5}{*}{$800 \mathrm{~kg}$} \\
\hline $25 \%$ & 1678,36 & 1737,46 & 1691,36 & 1629,28 & 1518,96 & \\
\hline $50 \%$ & 1727,98 & 1725,32 & 1726,2 & 1590,81 & 1566,44 & \\
\hline $75 \%$ & 1653,24 & 1661,72 & 1670,91 & 1572,28 & 1531,68 & \\
\hline $100 \%$ & 1654,6 & 1667,82 & 1678,49 & 1620,27 & 1318,56 & \\
\hline
\end{tabular}

Nilai stabilitas yang terdapat pada Tabel 3 di atas diperoleh nilai tertinggi dari benda uji dengan kadar filler batu tabas $0 \%$ (semen $100 \%$ ) dengan kadar aspal 6\% yaitu sebesar $1749,29 \mathrm{~kg}$, sedangkan nilai terendah diperoleh benda uji dengan kadar filler batu tabas $100 \%$ pada kadar aspal $7 \%$ yaitu sebesar $1318,56 \mathrm{~kg}$. Nilai stabilitas mengalami penurunan pada kadar aspal 7\% karena kandungan bitumen yang tinggi pada campuran sehingga menyebabkan benda uji menjadi lebih plastis. Hasil nilai stabilitas secara keseluruhan benda uji telah memenuhi syarat Bina Marga (2018), yaitu minimal $800 \mathrm{~kg}$.
Flow merupakan besar deformasi yang terjadi di awal pembebanan hingga stabilitas menurun yang menunjukkan besar deformasi dari campuran perkerasan akibat menerima beban yang bekerja. Nilai flow/kelelehan yang terdapat pada Tabel 4 di atas diperoleh nilai terendah dari benda uji pada kadar filler batu tabas $75 \%$ dengan kadar aspal 5,5\% yaitu 1,64 $\mathrm{mm}$, sedangkan nilai tertinggi diperoleh benda uji dengan kadar filler batu tabas $100 \%$ pada kadar aspal $7 \%$ yaitu 4,88 $\mathrm{mm}$. Kandungan bitumen yang tinggi pada campuran akan menyebabkan aspal beton menjadi lebih plastis/lentur saat menerima beban lalu lintas. Hasil nilai flow sebagian besar benda uji telah memenuhi spesifikasi yang telah ditentukan oleh Bina Marga (2018), yaitu minimal $2 \mathrm{~mm}$ dan maksimal $4 \mathrm{~mm}$.

Tabel 4. Nilai Flow Aspal Beton AC-WC

\begin{tabular}{|c|c|c|c|c|c|c|c|}
\hline \multicolumn{8}{|c|}{ FLOW (mm) } \\
\hline \multirow{2}{*}{ \% Kadar Filler Batu Tabas } & \multicolumn{5}{|c|}{ \% Kadar Aspal Terhadap Berat Campuran } & \multicolumn{2}{|c|}{ Spesifikasi } \\
\hline & 5 & 5,5 & 6 & 6,5 & 7 & Min. & Max. \\
\hline $0 \%$ & 2,74 & 2,06 & 2,15 & 2,86 & 3,25 & \multirow{5}{*}{$2 \mathrm{~mm}$} & \multirow{5}{*}{$4 \mathrm{~mm}$} \\
\hline $25 \%$ & 2,66 & 2,29 & 2,33 & 3,3 & 3,9 & & \\
\hline $50 \%$ & 2,36 & 1,86 & 2,1 & 2,36 & 2,41 & & \\
\hline $75 \%$ & 2,03 & 1,64 & 2,39 & 2,1 & 2,99 & & \\
\hline $100 \%$ & 2,07 & 2,46 & 2,55 & 2,64 & 4,88 & & \\
\hline
\end{tabular}

Tabel 5. Nilai MQ Aspal Beton AC-WC

\begin{tabular}{|c|c|c|c|c|c|c|c|}
\hline \multicolumn{8}{|c|}{ MQ (kg/mm) } \\
\hline \multirow{2}{*}{$\begin{array}{c}\text { \% Kadar Filler } \\
\text { Batu Tabas }\end{array}$} & \multicolumn{5}{|c|}{ \% Kadar Aspal Terhadap Berat Campuran } & \multicolumn{2}{|c|}{ Spesifikasi } \\
\hline & 5 & 5,5 & 6 & 6,5 & 7 & Min. & Max. \\
\hline $0 \%$ & 626,23 & 849,99 & 829,44 & 527,26 & 455,74 & & \\
\hline $25 \%$ & 635,86 & 761,53 & 730,5 & 495,89 & 396,1 & & \\
\hline $50 \%$ & 761,79 & 936,14 & 836,32 & 694,83 & 663,36 & - & - \\
\hline $75 \%$ & 817,79 & 1114,63 & 707,66 & 750,08 & 521,27 & & \\
\hline $100 \%$ & 821,00 & 680,04 & 662,10 & 618,63 & 301,21 & & \\
\hline
\end{tabular}


MQ (Marshall Quotient) diperoleh dari perbandingan antara nilai stabilitas yang telah dikoreksi terhadap nilai kelelehan (flow) dan dinyatakan dalam satuan $\mathrm{kg} / \mathrm{mm}$ atau $\mathrm{kN} / \mathrm{mm}$. Hasil nilai MQ yang terdapat pada Tabel 5 diperoleh nilai tertinggi dari benda uji pada kadar filler batu tabas $75 \%$ dengan kadar aspal $5,5 \%$ yaitu $1114,63 \mathrm{~kg} / \mathrm{mm}$, kemudian pada kadar filler batu tabas $100 \%$ dengan kadar aspal 7\% mengalami penurunan hingga mencapai $301,21 \mathrm{~kg} / \mathrm{mm}$. Benda uji dengan variasi kadar aspal berdasarkan variasi kadar filler batu tabas akan mengalami penurunan pada kadar aspal 6\% akibat kandungan bitumen pada campuran yang tinggi sehingga stabilitas mengalami penurunan dan flow meningkat.
VMA (Void in Mineral Aggregate) merupakan rongga antar butiran agregat dalam campuran aspal yang telah dipadatkan, termasuk rongga udara dan rongga yang terisi aspal efektif. Nilai VMA pada Tabel 7 diperoleh nilai tertinggi dari benda uji pada kadar filler batu tabas $100 \%$ dengan kadar aspal $7 \%$ yaitu sebesar $16,01 \%$, sedangkan nilai VMA terendah diperoleh benda uji pada kadar filler batu tabas 50\% dengan kadar aspal 5\% yaitu sebesar $13,02 \%$. Nilai VMA pada aspal beton yang menggunakan variasi kadar filler batu tabas secara keseluruhan mengalami peningkatan seiring bertambahnya kadar aspal. Nilai minimal VMA menurut Bina Marga (2018) adalah 14\%

Tabel 6. Nilai VIM Aspal Beton AC-WC

\begin{tabular}{|c|c|c|c|c|c|c|c|}
\hline \multicolumn{8}{|c|}{ VIM (\%) } \\
\hline \multirow{2}{*}{$\begin{array}{c}\% \text { Kadar Filler Batu } \\
\text { Tabas }\end{array}$} & \multicolumn{5}{|c|}{ \% Kadar Aspal Terhadap Berat Campuran } & \multicolumn{2}{|c|}{ Spesifikasi } \\
\hline & 5 & 5,5 & 6 & 6,5 & 7 & Min. & Max. \\
\hline $0 \%$ & 4,16 & 4,47 & 4,03 & 3,69 & 3,31 & \multirow{5}{*}{$3 \%$} & \multirow{5}{*}{$5 \%$} \\
\hline $25 \%$ & 4,61 & 4,73 & 4,33 & 3,58 & 3,26 & & \\
\hline $50 \%$ & 4,38 & 4,46 & 4,37 & 3,09 & 3,34 & & \\
\hline $75 \%$ & 4,74 & 4,46 & 4,02 & 3,56 & 3,25 & & \\
\hline $100 \%$ & 4,54 & 4,56 & 3,99 & 3,49 & 3,44 & & \\
\hline
\end{tabular}

VIM (Void in Mixture) merupakan rongga udara yang dihasilkan dan ditentukan oleh susunan partikel agregat pada campuran serta ketidakseragaman bentuk dan ukuran agregat. Nilai VIM yang terdapat pada Tabel 6 diperoleh nilai tertinggi dari benda uji yang menggunakan kadar filler batu tabas $75 \%$ dengan kadar aspal 5\% yaitu sebesar $4,74 \%$, sedangkan nilai VIM terendah diperoleh pada benda uji yang menggunakan kadar filler batu tabas 50\% dengan kadar aspal 6,5\% yaitu sebesar 3,09\%. Nilai VIM menurut spesifikasi dari Bina Marga (2018), yaitu minimal 3\% dan maksimal 5\%.
Besar nilai VFA (Void Filled with Asphalt) dapat mempengaruhi kekedapan suatu campuran terhadap pengaruh udara dan air. Nilai VFA pada Tabel 8 diperoleh nilai tertinggi dari benda uji pada kadar filler batu tabas $75 \%$ dengan kadar aspal 7\% yaitu sebesar $87,34 \%$, sedangkan nilai VFA terendah diperoleh pada kadar filler batu tabas $75 \%$ dengan kadar aspal 5\% yaitu sebesar 76,27\%. Campuran yang menggunakan variasi kadar filler batu tabas mampu menghasilkan nilai VFA yang meningkat seiring bertambahnya kadar aspal dimana bitumen pada filler mampu mengisi pori-pori dalam campuran aspal beton padat.

Tabel 7. Nilai VMA Aspal Beton AC-WC

\begin{tabular}{ccccccc}
\hline \multicolumn{7}{c}{ VMA (\%) } \\
\hline $\begin{array}{c}\text { \% Kadar Filler Batu } \\
\text { Tabas }\end{array}$ & $\mathbf{5}$ & $\mathbf{5 , 5}$ & $\mathbf{6}$ & $\mathbf{6 , 5}$ & $\mathbf{7}$ & Spesifikasi \\
\cline { 2 - 6 } & 12,82 & 14,07 & 14,64 & 15,29 & 15,89 & \\
\hline $0 \%$ & 13,24 & 14,32 & 14,92 & 15,21 & 15,87 & \multirow{2}{*}{$14 \%$} \\
\hline $25 \%$ & 13,02 & 14,07 & 14,94 & 14,76 & 15,92 & \\
\hline $50 \%$ & 13,34 & 14,06 & 14,63 & 15,17 & 15,84 & \\
\hline $75 \%$ & 13,17 & 14,17 & 14,61 & 15,12 & 16,01 \\
\end{tabular}


Tabel 8. Nilai VFA Aspal Beton AC-WC

\begin{tabular}{ccccccc}
\hline & \multicolumn{7}{c}{ VFA (\%) } & Spesifikasi \\
\hline $\begin{array}{c}\text { \% Kadar Filler Batu } \\
\text { Tabas }\end{array}$ & $\mathbf{5}$ & $\mathbf{5 , 5}$ & $\mathbf{6}$ & $\mathbf{6 , 5}$ & $\mathbf{7}$ & Minimal \\
\cline { 2 - 6 } $0 \%$ & 79,92 & 78,87 & 82,16 & 84,6 & 87,04 \\
\hline $25 \%$ & 77,29 & 77,94 & 80,69 & 85,23 & 87,3 \\
& 78,47 & 78,92 & 80,25 & 88,24 & 86,86 & \multirow{2}{*}{$65 \%$} \\
\hline $50 \%$ & 76,27 & 78,95 & 82,23 & 85,37 & 87,34 \\
\hline $75 \%$ & 77,48 & 78,34 & 82,4 & 85,74 & 86,3 \\
\hline $100 \%$ & & & & & & \\
\hline
\end{tabular}

b) Pengujian Indeks Kekuatan Sisa

Hasil dari nilai Indeks Kekuatan Sisa (IKS) dengan variasi kadar filler batu tabas diperoleh nilai-nilai stabilitas dari perendaman 30 menit danperendaman 24 jam didalam waterbath dengan suhu $60^{\circ} \mathrm{C}$ yang dapat dilihat pada Tabel 9 .
IKS (Indeks Kekuatan Sisa) ditentukan untuk mengevaluasi ketahanan campuran aspal beton terhadap pengerusakan yang diakibatkan oleh pengaruh air dan efisiensi daya adhesi dari bahan ikat dan agregat awal (Ambarwati, dkk., 2009). Nilai IKS dari Tabel 9 di atas diperoleh

Tabel 9. Hasil Nilai Indeks Kekuatan Sisa

\begin{tabular}{|c|c|c|c|c|}
\hline \multirow{2}{*}{ Kadar Filler } & \multirow{2}{*}{ Kadar Aspal (\%) } & \multicolumn{2}{|c|}{ Stabilitas } & \multirow{2}{*}{ IKS (\%) } \\
\hline & & Perendaman 30 Menit & Perendaman 24 Jam & \\
\hline $\mathbf{a}$ & $\mathbf{b}$ & $\mathbf{c}$ & d & $e=d / c \times 100$ \\
\hline FBT $0 \%$ & 5 & 1917,74 & 1480,18 & 77,18 \\
\hline FBT $0 \%$ & 5,5 & 1866,98 & 1668,43 & 89,36 \\
\hline FBT $0 \%$ & 6 & 1786,94 & 1636,17 & 91,56 \\
\hline FBT $0 \%$ & 6,5 & 1497,53 & 1419,13 & 94,76 \\
\hline FBT $0 \%$ & 7 & 1509,67 & 1400,23 & 92,75 \\
\hline FBT $25 \%$ & 5 & 1734,51 & 1632,37 & 94,11 \\
\hline FBT $25 \%$ & 5,5 & 1766,72 & 1536,07 & 86,94 \\
\hline FBT $25 \%$ & 6 & 1732,96 & 1627,54 & 93,92 \\
\hline FBT $25 \%$ & 6,5 & 1728,98 & 1547,77 & 89,52 \\
\hline FBT $25 \%$ & 7 & 1539,55 & 1438,03 & 93,41 \\
\hline FBT $50 \%$ & 5 & 1782,11 & 1607,11 & 90,18 \\
\hline FBT $50 \%$ & 5,5 & 1771,02 & 1633,56 & 92,24 \\
\hline FBT $50 \%$ & 6 & 1780,40 & 1600,46 & 89,89 \\
\hline FBT $50 \%$ & 6,5 & 1714,49 & 1530,09 & 89,24 \\
\hline FBT $50 \%$ & 7 & 1595,24 & 1349,75 & 84,61 \\
\hline FBT $75 \%$ & 5 & 1685,64 & 1488,96 & 88,33 \\
\hline FBT $75 \%$ & 5,5 & 1713,17 & 1576,03 & 91,99 \\
\hline FBT 75\% & 6 & 1775,46 & 1507,37 & 84,90 \\
\hline FBT $75 \%$ & 6,5 & 1632,99 & 1603,22 & 98,18 \\
\hline FBT $75 \%$ & 7 & 1565,88 & 1468,71 & 93,79 \\
\hline FBT $100 \%$ & 5 & 1713,31 & 1575,65 & 91,97 \\
\hline FBT $100 \%$ & 5,5 & 1763,87 & 1510,47 & 85,63 \\
\hline FBT $100 \%$ & 6 & 1826,28 & 1657,74 & 90,77 \\
\hline FBT $100 \%$ & 6,5 & 1641,47 & 1475,71 & 89,90 \\
\hline FBT $100 \%$ & 7 & 1534,03 & 1391,46 & 90,71 \\
\hline
\end{tabular}


nilai terendah dihasilkan pada campuran yang menggunakan kadar filler batu tabas $100 \%$ dengan kadar aspal 5\% yaitu sebesar 77,18\% sehingga campuran mengalami kerusakan sebesar $22,82 \%$, sedangkan nilai IKS tertinggi diperoleh pada campuran yang menggunakan kadar filler batu tabas $75 \%$ dengan kadar aspal $6,5 \%$ yaitu sebesar $98,18 \%$ yang mengalami kerusakan yang dialami sebesar $1,82 \%$. Dari 25 benda uji yang dilakukan pengujian IKS, sebanyak 14 buah benda uji telah memenuhi syarat dimana benda uji tersebut mampu menahan kerusakan yang diakibatkan oleh pengaruh air. Syarat nilai IKS yang ditentukan oleh Bina Marga (2018) adalah minimal 90\%.

\section{PEMBAHASAN}

\section{Karakteristik Bahan Campuran AC- WC}

Hasil pengujian agregat kasar diperoleh berat jenis SSD agregat kasar 2,64 dan nilai penyerapan agregat kasar 2,39\%. Hasil pengujian agregat halus diperoleh berat jenis SSD agregat halus 2,29 dan nilai penyerapan agregat halus $1,48 \%$. Hasil pengujian berat jenis filler batu tabas pada kadar $0 \%$ (semen PC) sebesar 3,03, kadar 25\% sebesar 3,122 , kadar 50\% sebesar 3,033, kadar 75\% sebesar 3,02, dan kadar 100\% sebesar 3,08.

Hasil pengujian aspal diperoleh berat jenis aspal 1,03, nilai penetrasi aspal $66,55 \mathrm{~mm}$, titik lembek aspal diperoleh suhu $50,5^{\circ} \mathrm{C}$, daktilitas aspal diperoleh sebesar 130,33 $\mathrm{cm}$, titik nyala aspal pada suhu $339^{\circ} \mathrm{C}$ dengan titik bakar aspal pada suhu $344^{\circ} \mathrm{C}$, dan nilai kehilangan berat aspal sebesar $0,0 \%$. Hasil seluruh pengujian aspal tersebut telah memenuhi syarat dari Bina Marga (2018).

\section{Hubungan antara Kadar Aspal dengan Variasi Kadar Filler Batu Tabas ditinjau dari Parameter Marshall dan IKS}

a) Stabilitas

Kadarfiller batu tabas $0 \%$ dengan kadaraspal
$6 \%$ memperoleh nilai stabilitas tertinggi yai tu $1749,29 \mathrm{~kg}$. Nilai stabilitas dari seluruh benda uji pada tabel mengalami pen ingkatan hingga kadar aspal 6\%, lalu mengalami penurunan hingga kadar as pal $7 \%$. Hal ini dikarenakan benda uji as pal beton dengan kandungan variasi ka dar filler batu tabas pada kadar aspal 7\% mengandung lebih banyak bitumen sehingga campuranakanmengalamibleeding/lembek.

b) Flow

Kadar filler batu tabas $75 \%$ dengan kadar aspal 5,5\% memperoleh nilai flow terendah yaitu 1,64 mm, kemudian nilai tertinggi di peroleh pada kadar filler batu tabas 100\% dengan kadar aspal 7\% meningkat hingga mencapai nilai 4,88 mm. Nilai flow mempengaruhi kemampuan campuran aspal beton dalam menerima lendutan secara berulang sehingga terjadi alur (rutting) dan retak yang diakibatkan oleh repetisi beban tanpa mengalami kelelahan.

\section{c) MQ (Marshall Quotient)}

Nilai MQ mempengaruhi kekuatan dan fleksibilitas sehingga campuran beraspal yang memiliki nilai MQ tinggi bersifat leb ih kaku dan mudah mengalami keretakan, sedangkan campuran yang memiliki nilai MQ rendah bersifat lebih lentur sehingga mudah mengalami perubahan bentuk saat menerima beban.

d) VIM (Void in Mixture)

VIM menentukan tingkat keawetan campuran karena campuran aspal be ton yang menghasilkan nilai VIM ren dah akan lebih kedap air dan rapat diband ingkan dengan nilai VIM tinggi pada cam puran aspal beton yang memiliki pori be sarsehinggacampurantidakterlalukedapair.

e) VMA (Void in Mineral Aggregate)

Nilai VMA pada aspal beton secara keselu ruhan mengalami peningkatan seiring ber tambahnya kadar aspal. Jika nilai VMAyang dihasilkan tinggi, maka volume pori yang ter 
isipadaagregatdalamcampuranbesarsehing gaikatan antaragregatsemakinkuatdanrong gadalamcampuranaspalbetonsemakinkecil.

\section{f) VFA (Void Filled with Asphalt)}

Campuran yang menggunakan varia si kadar filler batu tabas mampu meng hasilkan nilai VFA yang meningkat seir ing bertambahnya kadar aspal dimana bitumen pada filler mampu mengisi po ri-pori dalam campuran aspal beton padat.

g) IKS (Indeks Kekuatan Sisa)

Nilai IKS terendah dihasilkan pada cam puran yang menggunakan kadar filler se men $100 \%$ dengan kadar aspal 5\% yaitu sebesar $77,18 \%$ sehingga campuran men galami kerusakan sebesar $22,82 \%$, sedan gkan nilai IKS tertinggi diperoleh pada campuran yang menggunakan kadar filler batu tabas $75 \%$ dengan kadar aspal $6,5 \%$ yai tu sebesar $98,18 \%$ sehingga kerusakan yang dialami sebesar $1,82 \%$. Hasil pengu jian IKS yang diperoleh dari 25 benda uji pada campuran variasi kadar filler batu tabas dengan variasi kadar aspal, sebanyak 14 ben da uji telah memenuhi syarat Direktorat Jendral Bina Marga (2018) yaitu minimal sebesar $90 \%$.

\section{SIMPULAN}

Nilai stabilitas pada campuran aspal beton AC-WC mengalami penurunan pada kadar aspal 7\% karena kandungan bitumen yang tinggi pada campuran. Flow/kelelehan yang memiliki kandungan bitumen tinggi pada campuran sehingga menyebabkan aspal beton menjadi lebih plastis/lentur saat menerima beban lalu lintas. MQ (Marshall Quotient) menurun pada kadar aspal 6\% akibat kandungan bitumen pada campuran yang tinggi sehingga stabilitas mengalami penurunan dan flow meningkat. VIM (Void in Mixture) menurun seiring bertambahnya kadar aspal. Filler batu tabas mampu mengisi rongga dalam campuran sehingga campuran lebih padat dan kedap air.
VMA (Void in Mineral Aggregate) meningkat seiring bertambahnya kadar aspal karena filler mampu mengisi rongga-rongga antar agregat dalam campuran sehingga ikatan antar agregat semakin kuat dan rongga dalam campuran aspal beton semakin kecil. VFA (Void Filled with Asphalt) meningkat seiring bertambahnya aspal dimana bitumen pada filler mampu mengisi rongga-rongga antar agregat sehingga selimut aspal semakin tebal. Dari 25 benda uji yang dilakukan pengujian IKS, sebanyak 14 buah benda uji telah memenuhi syarat dimana benda uji tersebut mampu menahan kerusakan yang diakibatkan oleh pengaruh air.

\section{DAFTAR RUJUKAN}

Ambarwati, L. \& Z. Arifin. 2009. Campuran Hot Rolled Sheet (HRS) Dengan Material Piropilit Sebagai Filler yang Tahan Hujan Asam. Teknik Sipil. Malang: Universitas Brawijaya.

Ambarwati, L., et al. 2009. Pengaruh Kadar Abu Batubara Sebagai Filler Terhadap

Karakteristik Campuran dan Indeks Kekuatan Sisa (IKS) pada Campuran Hot Rolled Sheet (HRS). Teknik Sipil. Malang: Universitas Brawijaya.

Bina Marga. 2018. Divisi 6 Perkerasan Aspal. Jakarta: Departemen Pekerjaan Umum. Intara, I., et al. 2013. Penggunaan Serbuk Batu Tabas Sebagai Pengganti Sebagian Semen Dalam Pembuatan Beton. Spektran 1.

Khuntia, S., et al. 2014. Prediction Of Mar shall Parameters Of Modified Bituminous Mixtures Using Artificial Intelligence Techniques. Transportation Science And Technology 3, 211-228.

SNI 03-1968-1990. Metode Pengujian Ten tang Analisis Saringan Agregat Halus dan Agregat Kasar.

SNI 06-2440-1991. Metode Pengujian Ke hilangan Berat Minyak dan Aspal.

SNI 1969-2008. Metode Pengujian Berat 
18 JURNAL BANGUNAN, VOL. 24, NO.2, OKTOBER 2019: 9-18

Jenis dan Penyerapan Air Agregat Kasar. SNI 1970-2008. Metode Pengujian Berat Jenis dan Penyerapan Air Agregat Halus. SNI 2417-2008. Metode Pengujian Keausan Agregat Dengan Mesin Abrasi Los Ange les.

SNI 2432-2011. Metode Pengujian Daktilitas Bahan-Bahan Aspal.

SNI 2434-2011. Metode Pengujian Titik Lembek Aspal Dengan Alat Cincin dan Bola.

SNI 2441-2011. Metode Pengujian Berat Jenis Aspal Padat.

SNI 2433-2011. Metode Pengujian Titik Nyala dan Titik Bakar.

SNI 2456-2011. Metode Pengujian Penetrasi Bahan-Bahan Bitumen.

Sukirman, S. 2003. Perkerasan Lentur Jalan
Raya. Bandung: Nova.

Sunartha, I. K. 2004. Pengaruh Penggunaan Serbuk Batu Tabas (Scoriae Basaltik) Sebagai Filler Dalam Campuran Lataston. Teknik Sipil. Yogyakarta: Un i ver s i t a s Atma Jaya Yogyakarta.

Tahir, A. 2009. Karakteristik Campuran Be ton Aspal (AC-WC) Dengan Menggu nakan Variasi Kadar Filler Abu Terbang Batu Bara. SMARTek 7: 256-278. Tahir, A. and A. Setiawan. 2009. Kinerja Durabilitas Beton Aspal Ditinjau Dari Fak tor Variasi Suhu Pemadatan dan Lama Perendaman. SMARTek 7: 45-61.

Zulfhazli, et al. 2016. Penggunaan Abu Batu Bara Sebagai Filler Pada Campuran Aspal Beton (AC-BC). Aceh: Universitas Mali kussaleh. 